\title{
Mixes of Carrot Juice and Some Fermented Dairy Products: Potentiality as Novel Functional Beverages
}

\author{
Amany E. El-Abasy, Hany A. Abou-Gharbia, Hamida M. Mousa, Mohammed M. Youssef*
}

Food Science and Technology Department, Faculty of Agriculture, Alexandria University, Alexandria, Egypt.

Email: ${ }^{*}$ m_m_youssef@yahoo.com

Received August $16^{\text {th }}, 2011$; revised October $2^{\text {nd }}, 2011$; accepted October $10^{\text {th }}, 2011$

\begin{abstract}
The present study aimed to formulate and evaluate yoghurt and Rayeb (Traditional Egyptian natural fermented milk) mixes with red and yellow carrot juices. Out of 16 different mixing ratios (Eight for yoghurt and eight for Rayeb), data indicated that the most significantly acceptable mixes as judged by panelists were: yoghurt-red carrot juice $(3: 1 \mathrm{v} / \mathrm{v})$, yoghurt-yellow carrot juice $(2: 1 \mathrm{v} / \mathrm{v})$, Rayeb-red carrot juice $(2: 1 \mathrm{v} / \mathrm{v})$ and Rayeb-yellow carrot juice $(4: 1 \mathrm{v} / \mathrm{v})$. The aforementioned mixes were further investigated versus their counterpart controls (yoghurt and Rayeb). It was obvious that the formulated mixes contained considerably higher concentrations of the bioactive components mainly, ascorbic acid and anthocyanins (red-carrot mixes) and $\beta$-carotene (yellow-carrot mixes) along with antioxidant activity (DMPD Radical Scavenging Activity) and higher counts of probiotic LAB, as compared to the controls.
\end{abstract}

Keywords: Yoghurt; Rayeb; Probiotics; Anthocyanins; $\beta$-Carotene; Antioxidants

\section{Introduction}

Although there is no consensus on the exact definition of the "Functional Food" term, according to the American Dietetic Association, functional food is defined as: Any modified food or food ingredient that may provide a health benefit beyond the traditional nutrients that contains [1]. Functional food development has enjoyed heightened interest by commercial, academic and governmental sectors over the past decade [2].

The interest in the role of phytochemicals especially as dietary antioxidants in human health has prompted research in the field of food science. Fruits and vegetables are good sources of antioxidants. Consequently, there are a number of commercial polyphenol rich beverages, which base their marketing strategies on antioxidant potency [3].

Carrot (Daucus carota L.) is an inexpensive and highly nutritious vegetable, since it contains appreciable amounts of vitamins $\mathrm{B}_{1}, \mathrm{~B}_{2}$ and $\mathrm{B}_{6}$ along with carotenes. Dietary carotenes are associated with lowering risk of many cancers. Meanwhile, vitamin A is an antioxidant which plays a key role in growth and repair of tissues in addition to help the body to fight with infections, keep eyes healthy, nourish epithelial tissues in the lungs and skin as well [4].

Extensively reviewed data about Leuconostoc, relative to their habitat, taxonomy, metabolism and genetics, their

\footnotetext{
${ }^{*}$ Corresponding author.
}

implications in health and safety, and their present and potential use in dairy technology and functional foods was done[5]. It is worth to mention that the development of probiotics in the last two decades has signaled an important advance in food industry. The number of scientific publications on probiotics has increased a lot stimulated by factors as exciting scientific and clinical findings using well-documented probiotic organisms [6].

The aim of the present work was to formulate mixes of carrot juice (yellow and red varieties) with two fermented dairy products namely, yoghurt and Rayeb, in order to design new functional beverages. Meanwhile, such beverages were evaluated from sensorial, physicochemical and microbiological points of view.

\section{Materials and Methods}

\subsection{Materials}

Fresh yellow and red carrots (Daucus carota) were purchased from local farm and immediately transferred to cooling room $\left(0^{\circ} \mathrm{C}\right.$ and $\left.90 \% \mathrm{RH}\right)$ until used.

Yoghurt and Rayeb milk (Traditional Egyptian natural fermented milk) were obtained from pilot plant belonging to Department of Dairy Science and Technology, Faculty of Agriculture, Alexandria University, Egypt.

\subsection{Preparation of Carrot Juice}

Both yellow and red carrots were "topped" and "tailed" 
using a sharp knife, thoroughly washed with tap water, trimmed and peeled using a hand peeler (Approximately $1.00 \mathrm{~mm}$ of the periderm was removed by peeling and 2 $\mathrm{cm}$ of both tip and top were also removed by trimming), and were cut into sticks by sharp knife $(1 \times 3 \times 1 \mathrm{~cm})$. The sticks were then blanched for $15 \mathrm{~min}$ in boiling water with a ratio of $1: 1 \mathrm{w} / \mathrm{v}$ carrot: water. The sticks along with blanching water were blended in a household blendor at a maximum velocity for $6 \mathrm{~min}$ to get fine paste. Juices were kept in polyethylene bags and frozen at $-18^{\circ} \mathrm{C}$ until used.

\subsection{Preparation of Yoghurt-Carrot Juice Mixes}

One hundered $\mathrm{ml}$ of pasteurized milk were tempered to $40^{\circ} \mathrm{C}$ then inoculated with $2 \mathrm{~g}$ of commercial yoghurt starter culture (Streptococcus thermophilus and Lactobacillus delbrueckii ssp. Bulgaricus) obtained from Dairy Pilot Plant, Faculty of Agriculture, Alexandria University. Incubation was conducted at $45^{\circ} \mathrm{C}$ for $8 \mathrm{hr}$, then cooled to $4^{\circ} \mathrm{C}$. Mixes of milk, starter culture and yellow or red carrot juice were prepared by the same method using ratios at $1: 0,1: 1,2: 1,3: 1$ and $4: 1$ of milk to carrot juice, respectively.

\subsection{Preparation of Rayeb-Carrot Juice Mixes}

One hundred $\mathrm{ml}$ of non-pasteurized milk were tempered to $40^{\circ} \mathrm{C}$ and fermented with natural flora for $24 \mathrm{hr}$. Mixes of milk and yellow or red carrot juice were prepared by the same method using ratios at 1:0, 1:1, 2:1, 3:1 and 4:1 of milk to carrot juice, respectively. Fermentation was stopped by lowering the temperature to $4^{\circ} \mathrm{C}$ and samples were held overnight at this degree.

\subsection{Sensory Evaluation}

Samples were subjected to sensory evaluation along with their controls. Ten trained panelists were asked to evaluate the samples according to the method described [7] on hedonic scale consisting of 9 points from 1 (Extremely dislike) to 9 (Extremely like). Colour, taste, consistency and overall acceptability were evaluated.

\subsection{Microbiological Analysis}

Food samples were aseptically removed from the bottles and $10 \mathrm{~g}$ from each sample were homogenized in $90 \mathrm{ml}$ of sterile distilled water. Serial dilutions were prepared and $1 \mathrm{ml}$ aliquots were plated in each specific medium and incubated at different temperatures, times and growth media as shown in Table 1.

\subsection{Gross Chemical Composition}

Moisture content was determined by drying the sample in vacuum oven at $70^{\circ} \mathrm{C}$ to a constant weight [10], method No. 945.43. Ash was determined by incineration the sample at $550^{\circ} \mathrm{C}$ in an electrical Muffle furnace [10], method No. 923.03 .

Crude protein $(\mathrm{N} \times 6.25)$ was determined according to AOAC method [10], method No. 2001.11. Fat content was determined according to Folch et al. method [12], using a mixture of chloroform and methanol $(2: 1 \mathrm{v} / \mathrm{v})$. Carbohydrate content, was calculated by difference.

\subsection{Determination of $\boldsymbol{\beta}$-Caroten}

Carotenoids were extracted from samples with $80 \%$ acetone $(1: 50 \mathrm{w} / \mathrm{v})$. Absorbance of the extract was measured at $480 \mathrm{~nm}$ using Speckol Spectrocoluorimeter (Spekol 11, Carl Zeiss Jena, Germany). The $\beta$-carotene concentration was figured out by using the extinction coefficient $\left(E_{\mathrm{lcm}}^{1 \%}\right)$ of $2273[13,14]$.

\subsection{Determination of Anthocyanins}

Anthocyanins were extracted with $1 \%$ conc. $\mathrm{HCl}$ in $95 \%$ methanol $(\mathrm{v} / \mathrm{v})$. The ratio between sample and solvent was 1:50 (w/v). The micromolar concentration of anthocyanins in the extracts was obtained by multiplying the absorbance at $530 \mathrm{~nm}$ by 33.3 based on the molar extinction coefficient $(1.0 \mathrm{~cm}$ light path) of cyanidine chloride being 30,000 [15]. Anthocyanin content was calculated as $\mathrm{mg}$ cyanidine chloride/g sample.

Table 1. Media and incubation conditions used for microbiological analysis.

\begin{tabular}{cccc}
\hline Microbiological analysis & & & \\
\hline Total aerobic mesophilic bacteria & 48 & Temperature $\left({ }^{\circ} \mathrm{C}\right)$ & Growth medium \\
Molds and yeasts count & $72-120$ & $28-30$ & Nutrient Agar (NA) \\
Lactic acid bacteria (LAB) & $72-90$ & 35 & Potato Dextrose Agar (PDA) \\
Detection of $E$. coli & 48 & 37 & MRS Agar \\
\hline
\end{tabular}

NA and PDA were prepared according to Difco [8] and Badawy [9]. LB was presented according to AOAC method 988 [10]. MRS Agar was prepared according to Man [11]. 


\subsection{DMPD Radical Scavenging Activity}

Antioxidant activity was measured using N,N-Dimethyl$p$-phenylenediamine dihydrocholoride (DMPD). A dose response curve was derived for ascorbic acid by plotting the absorbance at $505 \mathrm{~nm}$ as percentage of the uninhibited radical cation solution.

Antioxidant activity was expressed as ascorbic acid equivalent antioxidant capacity using the calibration curve plotted with different amounts of ascorbic acid [16].

\subsection{Statistical Analysis}

Data were expressed as mean of triplicates \pm SD. Data of sensory evaluation were subjected to analysis of variance (ANOVA) and Duncan's multiple range test to separate the treatment means [17]. The analysis was computed using SAS program.

\section{Results and Discussion}

\subsection{Sensory Properties of Yoghurt-Carrot Juice Mixes}

Data presented in Table 2 reveal that the colours of yoghurt-red carrot juice mixes at different ratios were less scored than the control, with ratio of 3:1 being the only exception. In accordance, the taste of the control was higher scored than all mixes. In contrast, scores given for consistency of mixes were significantly comparable to the control. As for the overall acceptability, significant differences could be traced between the control and mixes. Since the mix at ratio 3:1 possessed the highest score for the overall acceptability, it was chosen to be investigated in details.

Table 2 shows that yoghurt-yellow carrot juice (YYC) mix at ratio of 2:1 exhibited the highest score given by the panelists for the overall acceptability as compared to the control and the other mixes. Accordingly, the aforementioned mix was chosen for the further investigation.

\subsection{Chemical Composition of Yoghurt-Carrot Juice Mixes}

Data given in Table 3 indicate that the moisture content ranged between $86.04 \%$ and $89.30 \%$ for the control and mixes. The yoghurt red carrot juice (YRC) mix at 3:1 v/v had the highest crude protein content $(25.70 \%)$ and the lowest fat content $(29.06 \%)$ as compared to the control and yoghurt-yellow carrot juice (YYC) mix.

The control exhibited the highest ash content (5.31\%), while YYC had the least ash content being $4.16 \%$. Carbohydrate contents (Table 3) can be ascendingly ordered as followes: YYC (40.84\%), YRC (40.56\%) and the yoghurt control $(31.05 \%)$.

The YRC exhibited the highest iron content being $11.83 \mathrm{mg} / 100 \mathrm{~g}$ followed by the control $(10.34 \mathrm{mg} / 100 \mathrm{~g})$, while YYC was tailed behind $(9.01 \mathrm{mg} / 100 \mathrm{~g})$. The same trend was also observed for phosphorus content (Table 3).

Increment of iron and phosphrous in YRC mix can be explained on the basis that the resultant lactic acid due to fermentation improves the mineral availability by degradation of some components in the raw material, decrease in $\mathrm{pH}$ and growth of lactic acid bacteria is coupled to production of different organic acid [18]. It has been shown that metal chelates originating from vegetables, such as phytate, tannins and oxalate, may be degraded during fermentation as a result of microbial and/or plant enzymatic activities. In contrast, decline of iron and

Table 2. Sensory evaluation of the control yoghurt and its mixes with red and yellow carrot juices.

\begin{tabular}{|c|c|c|c|c|c|}
\hline \multirow{2}{*}{ Products } & \multirow{2}{*}{ Ratios v/v } & \multicolumn{4}{|c|}{ Sensory properties } \\
\hline & & Colour & Taste & Consistency & Overall acceptability \\
\hline \multirow{5}{*}{$\begin{array}{l}\text { Yoghurt-red carrot } \\
\text { juice mix (YRC) }\end{array}$} & Control & $8.4^{\mathrm{a}}$ & $7.0^{\mathrm{a}}$ & $7.1^{\mathrm{a}}$ & $7.5^{\mathrm{a}}$ \\
\hline & $1: 1$ & $6.1^{\mathrm{b}}$ & $4.9^{\mathrm{b}}$ & $6.8^{\mathrm{a}}$ & $6.0^{\mathrm{b}}$ \\
\hline & $2: 1$ & $6.7^{\mathrm{b}}$ & $4.8^{\mathrm{b}}$ & $6.6^{\mathrm{a}}$ & $6.0^{\mathrm{b}}$ \\
\hline & $3: 1$ & $6.9^{\mathrm{ab}}$ & $5.6^{\mathrm{b}}$ & $6.9^{\mathrm{a}}$ & $6.4^{\mathrm{a}}$ \\
\hline & $4: 1$ & $5.5^{\mathrm{b}}$ & $5.2^{\mathrm{b}}$ & $6.8^{\mathrm{a}}$ & $6.0^{\mathrm{b}}$ \\
\hline \multirow{5}{*}{$\begin{array}{l}\text { Yoghurt-yellow } \\
\text { carrot juice mix } \\
\text { (YRC) }\end{array}$} & Control & $7.1^{\mathrm{ab}}$ & $5.9^{\mathrm{a}}$ & $5.0^{\mathrm{bc}}$ & $6.1^{\mathrm{ab}}$ \\
\hline & $1: 1$ & $6.6^{\mathrm{ab}}$ & $5.0^{\mathrm{ab}}$ & $6.1^{\mathrm{ab}}$ & $5.9^{\mathrm{ab}}$ \\
\hline & $2: 1$ & $7.4^{\mathrm{b}}$ & $4.3^{\mathrm{b}}$ & $6.5^{\mathrm{a}}$ & $6.4^{\mathrm{a}}$ \\
\hline & $3: 1$ & $5.9^{\mathrm{b}}$ & $4.8^{\mathrm{ab}}$ & $4.7^{\mathrm{c}}$ & $5.3^{\mathrm{bc}}$ \\
\hline & 4: 1 & $6.3^{\mathrm{ab}}$ & $5.0^{\mathrm{ab}}$ & $4.1^{\mathrm{c}}$ & $4.9^{\mathrm{c}}$ \\
\hline
\end{tabular}

Means in a column within the same mix not sharing the same superscript are significantly different at $\mathrm{P}<0.05$. 
Table 3. Chemical composition (on dry weight basis) and microbial counts of yoghurt and its mixes with red and yellow carrot juices.

\begin{tabular}{|c|c|c|c|}
\hline $\begin{array}{ll} & \text { Products } \\
\text { ns }\end{array}$ & Control & $\begin{array}{c}\text { Yoghurt-red carrot } \\
\text { (YRC) juice mix 3:1 v/v }\end{array}$ & $\begin{array}{c}\text { Yoghurt-yellow carrot juice } \\
\text { (YYC) mix 2:1 v/v }\end{array}$ \\
\hline Moisture (\%) & $87.35 \pm 0.05$ & $89.30 \pm 0.04$ & $86.04 \pm 0.02$ \\
\hline Crude protein (\%) & $23.94 \pm 0.09$ & $25.70 \pm 0.00$ & $18.05 \pm 0.01$ \\
\hline Total fat (\%) & $39.7 \pm 0.32$ & $29.06 \pm 0.23$ & $36.95 \pm 0.02$ \\
\hline Ash (\%) & $5.31 \pm 0.02$ & $4.68 \pm 0.01$ & $4.16 \pm 0.01$ \\
\hline Carbohydrates (\%) & 31.05 & 40.56 & 40.84 \\
\hline Iron $(\mathrm{mg} / 100 \mathrm{~g})$ & $10.34 \pm 0.07$ & $11.83 \pm 0.01$ & $9.01 \pm 0.03$ \\
\hline Phosphorus (mg/100g) & $2300 \pm 0.49$ & $2370 \pm 0.41$ & $2090 \pm 0.06$ \\
\hline Ascorbic acid (mg/100g) & $13.04 \pm 0.02$ & $23.64 \pm 0.02$ & $12.39 \pm 0.00$ \\
\hline$\beta$-caroten $(\mathrm{mg} / 100 \mathrm{~g})$ & 0.00 & $3.68 \pm 0.001$ & $16.55 \pm 0.00$ \\
\hline Anthocyanins (mg/100g) & 0.00 & $22.05 \pm 0.04$ & 0.00 \\
\hline Antioxidants (mg/100g) & $15.06 \pm 0.59$ & $26.42 \pm 0.24$ & $32.42 \pm 0.05$ \\
\hline Total soluble solids (\%) & 7.00 & 6.00 & 7.00 \\
\hline $\mathrm{pH}_{1}$ & 6.40 & 6.36 & 6.04 \\
\hline $\mathrm{pH}_{2}$ & 4.40 & 4.10 & 4.20 \\
\hline Total mesophilic bacteria ${ }^{*}$ & $2.22 \times 10^{2}$ & $2.22 \times 10^{2}$ & $2.22 \times 10^{2}$ \\
\hline Moulds and Yeasts ${ }^{*}$ & 0.00 & 0.00 & 0.00 \\
\hline Escherichia coli ${ }^{*}$ & 0.00 & 0.00 & 0.00 \\
\hline Lactic acid bacteria $(\mathrm{LAB})^{*}$ & $2.3 \times 10^{6}$ & $2.8 \times 10^{6}$ & $3.99 \times 10^{6}$ \\
\hline
\end{tabular}

${ }^{*} \mathrm{CFU} / \mathrm{g} ; \mathrm{pH}_{1}$ : Prior to fermentation; $\mathrm{pH}_{2}$ : Immediately after fermentation. Results are expressed as means $\pm \mathrm{SD}$.

phosphrous in YYC mix may be due to the translocation of minerals from the solution into lactic acid bacteria cells for various functions in the bacteria [18].

It is worth to mention that YRC mix had almost double vitamin $\mathrm{C}$ content as compared to each of the control and YYC mix (Table 3). Notwithstanding, the YYC mix exhibited almost 5 folds of $\beta$-carotene as compared to YRC mix, while $\beta$-carotene could not be traced in the control (Table 3).

No anthocyanins could be detected in any of the control or YYC mix, on contrary to YRC mix which possessed considerable amount of anthocyanins being 22.05 $\mathrm{mg} / 100 \mathrm{~g}$. Table 3 indicates that YYC mix had more than double of antioxidants as the control had (32.42 versus $15.06 \mathrm{mg} / 100 \mathrm{~g}$ ). Meanwhile, YRC mix contained higher content $(26.42 \mathrm{mg} / 100 \mathrm{~g})$, than its counterpart of the control $(15.06 \mathrm{mg} / 100 \mathrm{~g})$.

Total soluble solids were $7.0,6.0$ and 7.0 for the control, YRC and YYC, respectively (Table 3). The $\mathrm{pH}$ was measured twice (prior and immediately after fermentation). It was obvious that the $\mathrm{pH}$ values declined consid- erably form 6.40 to 4.40 (control), from 6.36 to 4.10 (YRC mix) and from 6.04 to 4.20 (YY mix) as shown in Table 3. Such declines in $\mathrm{pH}$ values are suspected due to formation of lactic acid during fermentation.

\subsection{Microbial Counts of Yoghurt-Carrot Juice Mixes}

Counts of total mesophilic bacteria were quite identical $\left(2.22 \times 10^{2} \mathrm{CFU} / \mathrm{g}\right)$ for the yoghurt control, YRC mix and YYC mix. On the other hand, neither moulds and yeasts nor Escherichia coli could be detected neither in the control nor in the two mixes under investigation (Table 3 ).

The point of interest is that the count of lactic acid bacteria (LAB) increased considerably from $2.3 \times 10^{6}$ $\mathrm{CFU} / \mathrm{g}$ (control) to $2.8 \times 10^{6} \mathrm{CFU} / \mathrm{g}$ (YRC mix) and 3.99 $\times 10^{6} \mathrm{CFU}$ (YYC), as it is shown in Table 3. Such increment of LAB counts can be attributed to the presence of carrot juice as a source of nutrients for bacteria. In accordance in other studies synbiotic potential of carrot juice supplemented with Lactobacillus spp. was dis- 
cussed [19]. Their data revealed that both bacterial strains namely lactobacillus rhamnosus and Lactobacillus bulgaricus were capable of growing in carrot juice, reaching nearly $5 \times 10^{9} \mathrm{CFU} / \mathrm{g}$ after a $48 \mathrm{~h}$ fermentation and the $\mathrm{pH}$ was reduced to $3.5-3.7$ or below [19]. Meanwhile, some biochemical characteristics of the fermented juice, such as $\beta$-carotene content and antioxidant activity, were also preserved, indicating that the metabolism of the Lactobacillus spp. did not degrade these components after 4 weeks of storage at $4^{\circ} \mathrm{C}$.

\subsection{Sensory Properties of Rayeb-Carrot Juice Mixes}

Data presented in Table 4 indicate that colours of Rayeb red-carrot juice (RRC) mixes were significantly comparable to the control at $1: 1$ and $3: 1$ ratios $(\mathrm{v} / \mathrm{v})$. No significant differences in taste scores could be figured out regarding RRC mixes. In contrast, these mixes were significantly different from the control in terms of their consistencies. As for overall acceptability, all mixes with an exception of $1: 1$ ratio mix were significantly comparable to the control. The $2: 1$ ratio mix was chosen for the further investigation, since it gained the highest score given for overall acceptability among the four RRC mixes.

Rayeb-yellow carrot juice (RYC) mix at 4:1 ratio was significantly similar to the control in terms of its colour and taste. Meanwhile, RYC mix at 3:1 ratio was significantly similar to the control in terms of consistency. The RYC mix at 4:1 ratio was chosen for further investigation because it had the highest score given by panelists for the overall acceptability as compared to the other RYC mixes.

\subsection{Chemical Composition of Rayeb-Carrot Juice Mixes}

Table 5 shows the chemical composition (on dry weight basis) of Rayeb (Natural fermented milk) and its mixes with red (RRC) and yellow (RYC) carrot juices. The RRC mix $(2: 1 \mathrm{v} / \mathrm{v})$ possessed the highest moisture content being $89.46 \%$, and the RYC mix $(4: 1 \mathrm{v} / \mathrm{v})$ had the lowest moisture content $(85.35 \%)$, while the control exhibited moisture content of $87.81 \%$. Notwithstanding, crude protein content ranged between $29.75 \%$ (RYC) and $35.10 \%$ (Control). Accordingly, mixing of Rayeb milk with carrot juice resulted in decline of crude protein content. The RYC mix exhibited the highest total fat content (34.28\%) as compared to $30.70 \%$ (RRC mix) and $33.80 \%$ (Control). Ash content varied from $4.30 \%$ (RYC mix) to $5.89 \%$ (RRC mix). As for carbohydrate contents, a range from $25.69 \%$ (Control) to $32.18 \%$ (RRC mix) was figured out.

Iron content varied from $13.22 \mathrm{mg} / 100 \mathrm{~g}$ (RYC mix) to $17.14 \mathrm{mg} / 100 \mathrm{~g}$ (RRC). Increment and decrease of iron content due to fermentation can be explained on the basis discussed previously for yoghurt-carrot juice mix. On the other hand, phosphorus content decreased in the mix as compared to its counterpart in the control (Table 5).

The RRC mix explored the highest ascorbic acid content $(32.84 \mathrm{mg} / 100 \mathrm{~g})$ as compared to the value of 17.47 $\mathrm{mg} / 100 \mathrm{~g}$ (RYC) and $20.99 \mathrm{mg} / 100 \mathrm{~g}$ (Control). Meanwhile, it was obvious that RYC mix had almost twice content of $\beta$-carotene as compared to RRC mix versus nil for control (Table 5).

The RRC mix was the only product which contains appreciable amount $(37.16 \mathrm{mg} / 100 \mathrm{~g})$ of anthocyanins

Table 4. Sensory evaluation of the control Rayeb and its mixes with red and yellow carrot juices.

\begin{tabular}{|c|c|c|c|c|c|}
\hline \multirow{2}{*}{ Products } & \multirow{2}{*}{ Ratios v/v } & \multicolumn{4}{|c|}{ Sensory properties } \\
\hline & & Colour & Taste & Consistency & Overall acceptability \\
\hline \multirow{5}{*}{$\begin{array}{l}\text { Rayeb-red carrot } \\
\text { juice mix }\end{array}$} & Control & $7.5^{\mathrm{a}}$ & $7.0^{\mathrm{a}}$ & $7.8^{\mathrm{a}}$ & $7.4^{\mathrm{a}}$ \\
\hline & $1: 1$ & $6.8^{\mathrm{ab}}$ & $6.5^{\mathrm{a}}$ & $6.8^{\mathrm{b}}$ & $6.6^{\mathrm{b}}$ \\
\hline & 2: 1 & $6.6^{\mathrm{b}}$ & $6.6^{\mathrm{a}}$ & $7.1^{\mathrm{ab}}$ & $7.0^{\mathrm{ab}}$ \\
\hline & 3: 1 & $6.7^{\mathrm{ab}}$ & $6.6^{\mathrm{a}}$ & $7.1^{\mathrm{ab}}$ & $6.9^{\mathrm{ab}}$ \\
\hline & 4: 1 & $6.6^{\mathrm{b}}$ & $6.5^{\mathrm{a}}$ & $7.0^{\mathrm{ab}}$ & $6.8^{\mathrm{ab}}$ \\
\hline \multirow{5}{*}{$\begin{array}{l}\text { Rayeb-yellow carrot } \\
\text { juice mix }\end{array}$} & Control & $8.1^{\mathrm{a}}$ & $7.4^{\mathrm{a}}$ & $6.9^{\mathrm{a}}$ & $7.5^{\mathrm{a}}$ \\
\hline & $1: 1$ & $6.2^{\mathrm{b}}$ & $5.8^{\mathrm{b}}$ & $4.9^{\mathrm{b}}$ & $5.5^{\mathrm{c}}$ \\
\hline & 2: 1 & $6.4^{\mathrm{b}}$ & $6.4^{\mathrm{ab}}$ & $5.5^{\mathrm{b}}$ & $6.3^{\mathrm{bc}}$ \\
\hline & 3: 1 & $6.2^{\mathrm{b}}$ & $6.6^{\mathrm{ab}}$ & $6.0^{\mathrm{ab}}$ & $6.4^{\mathrm{b}}$ \\
\hline & 4: 1 & $7.5^{\mathrm{a}}$ & $6.5^{\mathrm{ab}}$ & $5.7^{\mathrm{b}}$ & $6.5^{\mathrm{b}}$ \\
\hline
\end{tabular}

Means in a column within the same mix not sharing the same superscript are significantly different at $\mathrm{P}<0.05$. 
Table 5. Chemical composition (on dry weight basis) and microbial counts of Rayeb and its mixes with red and yellow carrot juices.

\begin{tabular}{|c|c|c|c|}
\hline Determinations $\quad$ Products & Control & Rayeb-red carrot juice mix 2:1 v/v (RRC) & Rayeb-yellow carrot juice mix $4: 1 \mathrm{v} / \mathrm{v}$ (RYC) \\
\hline Moisture (\%) & $87.81 \pm 0.26$ & $89.46 \pm 0.01$ & $85.35 \pm 0.04$ \\
\hline Crude protein $(\%)$ & $35.10 \pm 0.00$ & $31.23 \pm 0.00$ & $29.75 \pm 0.12$ \\
\hline Total fat (\%) & $33.80 \pm 0.14$ & $30.70 \pm 0.19$ & $34.28 \pm 0.32$ \\
\hline Ash (\%) & $5.41 \pm 0.01$ & $5.89 \pm 0.001$ & $4.30 \pm 0.01$ \\
\hline Carbohydrates (\%) & 25.69 & 32.18 & 31.67 \\
\hline Iron $(\mathrm{mg} / 100 \mathrm{~g})$ & $15.22 \pm 0.15$ & $17.14 \pm 0.04$ & $13.22 \pm 0.16$ \\
\hline Phosphorus (mg/100g) & $2290 \pm 2.48$ & $2060 \pm 0.82$ & $1870 \pm 2.32$ \\
\hline Ascorbic acid (mg/100g) & $20.99 \pm 0.01$ & $32.84 \pm 0.001$ & $17.47 \pm 0.02$ \\
\hline$\beta$-caroten $(\mathrm{mg} / 100 \mathrm{~g})$ & 0.00 & $5.52 \pm 0.03$ & $10.34 \pm 0.01$ \\
\hline Anthocyanins (mg/100g) & 0.00 & $37.16 \pm 0.02$ & 0.00 \\
\hline Antioxidants (mg/100g) & $10.55 \pm 0.33$ & $24.03 \pm 0.53$ & $23.08 \pm 0.41$ \\
\hline Total soluble solids (\%) & 6.60 & 6.00 & 6.40 \\
\hline $\mathrm{pH}_{1}$ & 6.60 & 6.74 & 7.06 \\
\hline $\mathrm{pH}_{2}$ & 4.53 & 4.20 & 4.44 \\
\hline Total mesophilic bacteria* & $2.59 \times 10^{2}$ & $2.23 \times 10^{2}$ & $2.18 \times 10^{2}$ \\
\hline Moulds and Yeasts ${ }^{*}$ & 10 & 0.00 & 0.00 \\
\hline Escherichia coli $^{*}$ & 0.00 & 0.00 & 0.00 \\
\hline 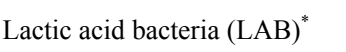 & $2.80 \times 10^{5}$ & $2.42 \times 10^{6}$ & $1.61 \times 10^{6}$ \\
\hline
\end{tabular}

${ }^{*} \mathrm{CFU} / \mathrm{g} ; \mathrm{pH}_{1}$ : Prior to fermentation; $\mathrm{pH}_{2}$ : Immediately after fermentation. Results are expressed as means $\pm \mathrm{SD}$.

versus nil for each of RYC mix and the control (Table 5). Antioxidants (mg/100g) increased considerably on mixing Rayeb with carrot juices. So, the RRC mix had 24.03 while RYC mix exhibited a value of 23.08 versus 10.55 for the control (Table 5).

Total soluble solids were $6.6 \%, 6.0 \%$ and $6.4 \%$ for the control, RRC mix and RYC mix, respectively (Table 5). Notwithstanding, the $\mathrm{pH}$ was measured prior to fermentation and immediately after fermentation. Dramatic declines in $\mathrm{pH}$ were figured out. Such declines were as follows: from 6.60 to 4.53 (Control), from 6.74 to 4.20 (RRC mix) and from 7.00 to 4.44 (RYC mix). Such declines in $\mathrm{pH}$ can be attributed to producing organic acids (mainly lactic acid) as a result of fermentation by lactic acid bacteria present in Rayeb.

\subsection{Microbial Counts of Rayeb-Carrot Juice Mixes}

Counts of total mesophilic bacteria were found to decline as a result of mixing Rayeb with carrot juices. In contrast, RRC and RYC mixes exhibited higher counts $\left(2.42 \times 10^{6}\right.$
$\mathrm{CFU} / \mathrm{g})$ and $\left(1.61 \times 10^{6} \mathrm{CFU} / \mathrm{g}\right)$ of lactic acid bacteria than the Rayeb control $\left(2.80 \times 10^{5} \mathrm{CFU} / \mathrm{g}\right)$. Such an elevation of lactic acid bacteria can be explained on the basis that presence of carrot juices in the medium of bacteria represents pivotal source of nutrients and thereby increase the growth rate of bacteria.

\section{Conclusion}

High quality and functional beverage mixes were able to be produced by mixing each of yoghurt and Rayeb (Traditional Egyptian natural fermented milk) with red carrot juice and yellow carrot juice. Such mixes can act as one of the most effective means for overcoming vitamin A deficiency. Moreover, these mixes contain high concentrations of natural antioxidants (vitamin $\mathrm{C}, \beta$-carotene and anthocyanins) along with lactic acid bacteria (LAB) which act as a very good probiotics. All these components possess health benefits, as it has been extensively reported in numerous literatures. Epidmiological studies have demonstrated or at least suggested numerous health effects related to probiotics, prebiotics and natural antioxidants [20]. 


\section{REFERENCES}

[1] A. Bloch and C. A. Thomson, "Position of the American Dietetic Association: Phytochemicals and Functional Foods," Journal of American Dietetic Association, Vol. 95, No. 4, 1995, pp. 493-496. doi:10.1016/S0002-8223(95)00130-1

[2] P. J. Jones and S. Jew, "Functional Food Development: Concept to Reality," Trends in Food Science \& Technology, Vol. 18, No. 7, 2007, pp. 387-390. doi:10.1016/j.tifs.2007.03.008

[3] E. Genzālez-Molina, D. A. Moreno and Garcia-Viguera. A New Drink Rich in Healthy Bioactive Combining Lemon and Pomegranate Juices," Food Chemistry, Vol. 115, No. 4, 2009, pp. 1364-1372. doi:10.1016/j.foodchem.2009.01.056

[4] B. Singh, P. S. Panesar and V. Nanda, "Utilization of Carrot Pomace for the Preparation of a Value Added Product," World Journal of Dairy \& Food Sciences, Vol. 1, No. 1, 2006, pp. 22-27.

[5] D. Hemme and C. Foucaud-Scheunemonn, "Leuconostoc, Characteristics, Use in Dairy Technology and Prospects in Functional Foods," International Dairy Journal, Vol. 14, No. 6, 2004, pp. 467-494. doi:10.1016/j.idairyj.2003.10.005

[6] F. C. Prado, J. L. Parada, A. Pandey and C. R. Soccoi. Review: Trends in Non-Dairy Probiotic Beverages," Food Research International, Vol. 41, No. 2, 2008, pp. 111-123. doi:10.1016/j.foodres.2007.10.010

[7] S. Hooda and S. Jood, "Organoleptic and Nutritional Evaluation of Wheat Biscuits Supplemented with Untreated and Treated Fenugreek Flour," Food Chemistry, Vol. 90, No. 3, 2005, pp. 427-435. doi:10.1016/j.foodchem.2004.05.006

[8] DIFCO, Difco Manual of Dehydrated Culture Media and Reagents for Microbiological and Clinical Laboratory Procedures," 8th Edition, Difco Laboratories, Detroit, 1948.

[9] D. M. Badawy, "Chemical, Technological and Microbiological Studies on Karkade (Hibiscus abdariffa) Petals Extract," M.Sc Thesis, Cairo University, Cairo, 2007.

[10] AOAC, Official Methods of Analysis of AOAC International, 17th Edition, Association of Official Analytical Chemists, Maryloand, 2000.
[11] J. C. Man, M. Rogosa and M. E. Sharpe, "A Medium for the Cultivation of Lactobacilli," Journal of Applied Bacterial, Vol. 23, No. 1, 1960, pp. 130-135. doi:10.1111/j.1365-2672.1960.tb00188.x

[12] J. Folch, M. Less and S. Stanley, "A Simple Method for the Isolation and Purification of Total Lipids from Animal Tissues," Journal Bio-Chemistry, Vol. 226, No. 1, 1957, pp. 497-509.

[13] A. Jensen, "Chlorophylls and Carotenoids," In: J. A. Hellebuts and J. S. Carigie, Eds., Hand Book of Physiological and Biochemical Methods, Cambridge University Press, London, 1978, pp. 59-70.

[14] A. Ben-Amotz and M. Avronm, "The Factors Which Determines Massive -Carotene Accumulation in the Halotolerant Alga Dunaliella bardawil," Plant Physiology, Vol. 72, No. 3, 1983, pp. 593-597. doi:10.1104/pp.72.3.593

[15] F. T. Halaweish and D. K. Dougall, "Sinapolyl Glucose Synthesis by Extracts of Wild Carrot Cell Cultures," Plant Science, Vol. 71, No. 2, 1990, pp. 179-184. doi:10.1016/0168-9452(90)90007-B

[16] V. Fogliano, V. Verde, G. Randazzo and A. Ritieni, "Method for Measuring Antioxidant Activity and Its Application to Monitoring the Antioxidant Capacity of Wines," Journal of Agricultural and Food Chemistry, Vol. 47, No. 3, 1999, pp. 1035-1040. doi:10.1021/jf980496s

[17] R. B. D. Steel and T. H. Torrie, "Principles and Procedures of Statistics," McGraw Hill Co., Boston, 1980.

[18] S.W. Bergqvist, A.S. Sandberg, N. G. Carlsson and T. Andlid, "Improved Iron Solubility in Carrot Juice Fermented by Homo- and Hetero-Fermentative Lactic Acid Bacteria," Food Microbiology, Vol. 22, No. 1, 2005, pp. 53-61. doi:10.1016/j.fm.2004.04.006

[19] F. Nazzaro, F. Fratianni, A. Sada and P. Orlando, "Synbiotic Potential of Carrot Juice Supplemented with Lactobacillus spp. and Inulin or Fructooligosaccharides," Journal of the Science of Food and Agriculture, Vol. 88, No. 13, 2008, pp. 2271-2276. doi:10.1002/jsfa.3343

[20] W. Grajek, A. Olejnik and A. Sip, "Probiotics, Prebiotics and Antioxidants as Functional Foods: A Review," Acta Biochimica Polonica, Vol. 52, No. 3, 2005, pp. 665-671. 